\title{
A National Agenda for Hydrogen Codes and Standards
}

Conference Paper NREL/CP-560-48306

May 2010

\section{Blake}

Presented at the International Symposium on Materials Issues in a Hydrogen Economy

Richmond, Virginia

November 12-15, 2007
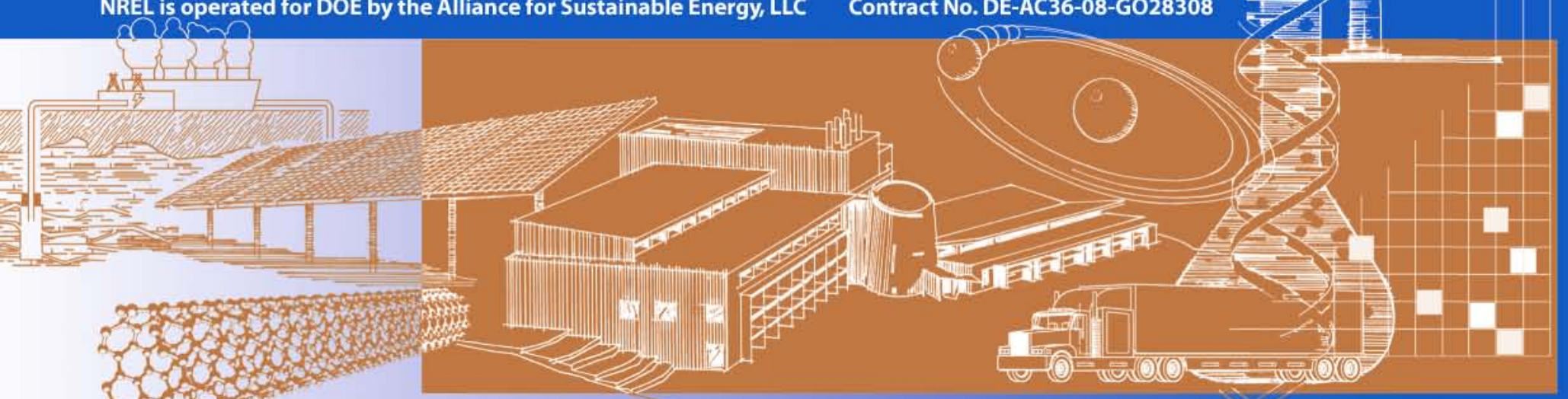


\section{NOTICE}

The submitted manuscript has been offered by an employee of the Alliance for Sustainable Energy, LLC (ASE), a contractor of the US Government under Contract No. DE-AC36-08-GO28308. Accordingly, the US Government and ASE retain a nonexclusive royalty-free license to publish or reproduce the published form of this contribution, or allow others to do so, for US Government purposes.

This report was prepared as an account of work sponsored by an agency of the United States government. Neither the United States government nor any agency thereof, nor any of their employees, makes any warranty, express or implied, or assumes any legal liability or responsibility for the accuracy, completeness, or usefulness of any information, apparatus, product, or process disclosed, or represents that its use would not infringe privately owned rights. Reference herein to any specific commercial product, process, or service by trade name, trademark, manufacturer, or otherwise does not necessarily constitute or imply its endorsement, recommendation, or favoring by the United States government or any agency thereof. The views and opinions of authors expressed herein do not necessarily state or reflect those of the United States government or any agency thereof.

Available electronically at http://www.osti.gov/bridge

Available for a processing fee to U.S. Department of Energy and its contractors, in paper, from:

U.S. Department of Energy

Office of Scientific and Technical Information

P.O. Box 62

Oak Ridge, TN 37831-0062

phone: 865.576.8401

fax: 865.576 .5728

email: mailto:reports@adonis.osti.gov

Available for sale to the public, in paper, from:

U.S. Department of Commerce

National Technical Information Service

5285 Port Royal Road

Springfield, VA 22161

phone: 800.553.6847

fax: 703.605.6900

email: orders@ntis.fedworld.gov

online ordering: http://www.ntis.gov/ordering.htm 


\title{
A NATIONAL AGENDA FOR HYDROGEN CODES AND STANDARDS
}

\author{
CHAD BLAKE \\ National Renewable Energy Laboratory
}

1617 Cole Boulevard

Golden, CO, 80401

\begin{abstract}
This paper provides an overview of hydrogen codes and standards with an emphasis on the national effort supported and managed by the U.S. Department of Energy (DOE). With the help and cooperation of standards and model code development organizations, industry, and other interested parties, DOE has established a coordinated national agenda for hydrogen and fuel cell codes and standards. With the adoption of the Research, Development, and Demonstration Roadmap and with its implementation through the Codes and Standards Technical Team, DOE helps strengthen the scientific basis for requirements incorporated in codes and standards that, in turn, will facilitate international market receptivity for hydrogen and fuel cell technologies.
\end{abstract}

\subsection{Introduction}

Large quantities of hydrogen have been used safely as a chemical feedstock and industrial gas for many years. Standards, codes, and regulations governing its storage, distribution, and use at industrial sites are well established. The use of hydrogen as an energy carrier for consumer markets is expected to grow over the next decade, and the development and promulgation of codes and standards for this use are essential to establish a market-receptive environment for commercial hydrogen products and systems.

Hydrogen standards are typically written under a consensus process by technical committees representing a cross-section of interested parties and issued in the U.S. by organizations such as the American Society of Mechanical Engineers (ASME) for pressure vessels, pipelines, and piping; the Compressed Gas Association (CGA) for pressure vessel operation and maintenance; and the Underwriters Laboratory for product certification. In the U.S., the American 
National Standards Institute (ANSI) facilitates the development of national standards by accrediting the procedures of standards developing organizations (SDOs) such as those mentioned above [1].

For hydrogen energy use in the U.S., the International Code Council (ICC) and the National Fire Protection Association (NFPA) are the two principal model code development organizations. The ICC develops and publishes a family of model codes; the most relevant for hydrogen energy are the International Fire Code (IFC), International Fuel Gas Code (IFGC), International Building Code (IBC), and International Mechanical Code (IMC) [2]. The NFPA develops and publishes both standards and codes [3]. For hydrogen energy, the most widely used of these are NFPA 55 (Standard for the Storage, Use, and Handling of Compressed Gases and Cryogenic Fluids in Portable and Stationary Containers, Cylinders, and Tanks), NFPA 52 (Vehicular Fuel Systems Code), and NFPA 30A (Code for Motor Fuel Dispensing Facilities and Repair Garages). The NFPA is currently incorporating all of its provisions for hydrogen into a single document, NFPA 2, Hydrogen Technologies, which is scheduled for publication in 2010.

The adoption and enforcement of codes and standards in the U.S. takes place under the jurisdiction of some 44,000 entities that include city, county, and state governments, as well as special districts such as port and tunnel authorities. Regulations make use of existing standards, either by incorporating appropriate sections of the standards (incorporation by transcription), or by referring to those sections (incorporation by reference). The extremely decentralized enforcement of codes and standards means that the permitting process for hydrogen fuel facilities can be very cumbersome.

The federal government plays a limited role in the development, adoption, and enforcement of codes and standards, but federal safety regulations are incorporated in the Code of Federal Regulations (CFR). Those that apply to hydrogen are embodied primarily in 49 CFR (1995) and 29 CFR (1996), under the jurisdictions of the Department of Transportation (DOT) and Occupational Safety and Health Administration (OSHA), respectively. The DOT regulates the transportation of hydrogen. The OSHA regulates the safe handling of hydrogen in the work place. OSHA regulations are intended to provide worker safety for the industrial use of hydrogen [5].

While most industrialized countries have adopted regulations, codes, and standards (RCS) that govern the use of hydrogen, many of these countries also 
support the development of international standards to facilitate international trade and commerce. For hydrogen energy, the key international SDOs are the International Organization for Standardization (ISO) and the International Electrotechnical Commission (IEC). Information about domestic and international hydrogen RCS, current activities of relevant ISO and IEC technical committees, including draft standards under preparation or review, can be found at www.fuelcellstandards.com, a website supported by the U.S. Department of Energy (DOE). Another useful source of information on hydrogen safety, codes and standards is the Hydrogen Safety Report, a monthly newsletter published by the National Hydrogen Association (NHA) at www.hydrogensafety.info, also supported by DOE.

\subsection{DOE Program for Hydrogen Codes and Standards}

For the past decade, the Office of Hydrogen, Fuel Cells and Infrastructure Technologies in DOE has sponsored a collaborative national effort by government and industry to prepare, review, and promulgate codes and standards needed to expedite hydrogen infrastructure development and to help enable the emergence of hydrogen as a significant energy carrier. In addition, DOE has worked to harmonize national and international standards, codes, and regulations that are essential for the safe use of hydrogen by consumers in the U.S. and throughout the world. The National Renewable Energy Laboratory (NREL) provides technical and programmatic support to DOE for this effort.

DOE has also launched a comprehensive research, development, and demonstration (RD\&D) effort to obtain the data needed to establish a scientific basis for requirements incorporated in hydrogen codes and standards. This RD\&D is planned, conducted, and evaluated in collaboration with industry through the U.S. FreedomCAR and Fuel Partnership formed to examine and advance pre-competitive research and development of technologies to enable high volume production of affordable hydrogen fuel cell vehicles and the national hydrogen infrastructure necessary to support them. The codes and standards activities of the Partnership are conducted through the Codes and Standards Technical Team that adopted a Roadmap to guide the RD\&D.

\subsection{National Templates}

Over the past several years, a coordinated national agenda for hydrogen and fuel cell codes and standards has emerged through DOE leadership and the support 
and collaboration of industry and key standards and model code development organizations (SDOs and CDOs). For example, hydrogen is recognized as a fuel gas, and hydrogen applications are incorporated in the 2003 and 2006 editions of the ICC model codes. Provisions for the safe use of hydrogen are included in ICC's International Building, Residential, Fire, Mechanical, and Fuel Gas Codes. Also, NFPA has incorporated hydrogen safety requirements into its family of codes and standards, as noted above. The consolidation of all hydrogen safety requirements into a single document (NFPA 2) will be a major step toward development of a national hydrogen code.

A key to the success of the national hydrogen and fuel cell codes and standards development efforts to date has been the creation and implementation of national templates through which DOE, NREL, and the major SDOs and CDOs coordinate the preparation of critical standards and codes for hydrogen and fuel cell technologies and applications. The national templates have helped the DOE to create and maintain a coordinated national agenda for hydrogen and fuel cell codes and standards. DOE leadership has coincided with the emergence of heightened national and international interest in hydrogen energy in general and in codes and standards in particular.

The national templates have been accepted by the major SDOs and CDOs in the U.S., the FreedomCAR and Fuel Partnership, key industry associations, and many state and local governments as the guideposts for the coordinated development of standards and model codes. All of the relevant major SDOs and CDOs in the U.S. are part of this national effort: the American National Standards Institute (ANSI), American Society of Mechanical Engineers (ASME), American Society of Testing and Materials (ASTM), Compressed Gas Association (CGA), CSA America, International Code Council (ICC), National Fire Protection Association (NFPA), Society of Automotive Engineers (SAE), and Underwriters Laboratories (UL). Industry participants include the FreedomCAR-Fuel Partnership (Chrysler, Ford Motor Company, General Motors, BP, Chevron, ConocoPhillips, ExxonMobil, Shell Hydrogen); other industry members, such as Ballard Power Systems, General Electric, Plug Power, Hydrogenics, UTC Power; and industry associations, such as the American Petroleum Institute (API), National Hydrogen Association (NHA), and the US Fuel Cell Council (USFCC). Other federal agencies involved include the Department of Transportation (DOT) and the National Institute of Standards and Technology (NIST). Other organizations participate on an asneed basis. 
The objectives of the national templates are to:

- Establish by a consensus of the national codes and standards development organizations the CDO or SDO that will have the lead in the development of codes and standards for establishing safety requirements for specific components, subsystems and systems (as shown in the templates) and the organizations that will work collaboratively with (or in support of) the lead organization

- Minimize duplication of efforts in the codes and standards development

- Establish "boundaries" and interfaces among standards for components, subsystems, and systems and identify harmonization requirements across such standards

- Identify codes and standards development needs and gaps and identify the organizations that should have responsibility for addressing the gaps.

Implementation of the national templates is coordinated through the National Hydrogen and Fuel Cells Codes and Standards Coordinating Committee, created by DOE, NREL, NHA, and USFCC. The committee conducts monthly conference calls to update participants on current activities and to discuss key issues. In addition, the committee meets quarterly to coordinate codes and standards development and prevent duplication of effort, identify critical deficiencies and gaps in hydrogen codes and standards development that could have an adverse impact on market acceptance, determine a collaborative strategy and action plan to address critical gaps and deficiencies, and identify specific opportunities for organizations to work together in developing codes and standards. The minutes of conference calls and proceedings of meetings are posted at $\underline{\text { www.hydrogenandfuelcellsafety.info. }}$

DOE supports implementation of the templates through subcontracts with a number of SDOs and CDOs designated for lead roles on the templates. It should be noted that significant work to implement the templates is being done by organizations not funded by DOE. While the templates were not intended to specify which organizations should receive DOE funding, they have helped to solidify the roles of the organizations identified as having a lead role in developing a particular standard. 
In summary, the templates continue to function as the seminal documents that help to create a more unified national approach to the development of hydrogen and fuel cell codes and standards. The templates and the National Hydrogen and Fuel Cells Codes and Standards Coordinating Committee that was formed to manage the templates have created a "virtual national forum" for SDOs, CDOs, industry, government, and interested parties to address codes and standards issues, both immediate and long-term.

\subsection{Research, Development, and Demonstration for Codes and Standards}

The RD\&D Roadmap helps guide DOE activities that will provide data required for SDOs to develop performance-based codes and standards for a commercial hydrogen fueled transportation sector in the U.S. The Roadmap reflects the experience and priorities of the members of the FreedomCAR and Fuels Partnership, which include the DOE, energy companies (BP, Chevron, ConocoPhillips, ExxonMobil, Shell Hydrogen), and the automotive companies (Chrysler, Ford, General Motors) belonging to the U.S. Consortium for Automotive Research (USCAR). The contents of the Roadmap are reviewed and revised by the Partnership as needed to reflect changing needs and opportunities.

By evaluating specific needs for RD\&D, assessing the status of on-going RD\&D, and revising the Roadmap as needed, the Partnership will ensure new U.S. projects are efficiently leveraged and coordinated with those undertaken internationally. Through the International Partnership for the Hydrogen Economy (IPHE), DOE works with individual countries as well as contributing to global RD\&D efforts. Information requirements of international SDOs are considered to help align RD\&D projects with needs for code and standard development.

The Roadmap includes an assessment of existing hydrogen and fuel cell codes and standards and those that are in the process of being established domestically and internationally and identifies information needs and gaps related to those codes and standards for a hydrogen-based transportation system. The Codes and Standards Technical Team (CSTT) of the Partnership reviews RD\&D projects to address gaps and to provide documented research to SDOs on a continuing basis. 
The Roadmap is organized into four Focus Areas:

- Hydrogen Behavior

- Hydrogen-fueled Vehicles

- Hydrogen Fuel Infrastructure

- Fuel-Vehicle Interface

The technical goal for each of these Focus Areas is to gather sufficient information and validating experience on technology applications so that the responsible SDO or CDP can proceed with better data upon which to base requirements incorporated in its codes and standards. Each Focus Area is subdivided into key Target Areas, which identify important information needs for which information is required by SDOs and CDOs to fully develop codes and standards. Completion of RD\&D for the individual technical Target Areas, in conjunction with information distribution, is expected to result in the subsequent development of safe, performance-based codes and standards. The Roadmap will be implemented over the next five years as proposed in the timeline for the Focus Areas.

\subsection{Conclusion}

Two key needs for hydrogen safety in consumer applications are the incorporation of data and analysis from RD\&D into the codes and standards development process and the adoption and enforcement of these codes and standards by state and local code officials. DOE supports a comprehensive program to address both these aspects of hydrogen safety. For the first, DOE is working with the automobile and energy industries to identify and address high priority RD\&D to establish a sound scientific basis for requirements that are incorporated in hydrogen codes and standards. The high priority RD\&D needs are incorporated and tracked in a Roadmap adopted by the Codes and Standards Technical Team (CSTT) of the FreedomCAR and Fuel Partnership. DOE and its national laboratories conduct critical RD\&D and work with key standards and model code development organizations to help incorporate RD\&D results into the codes and standards process. To address the second aspect, DOE has, for example, launched an initiative to facilitate the permitting process for hydrogen fueling stations (HFS). A key element of this initiative will be a web-based information repository, a toolkit that includes information fact sheets, networking charts to encourage information exchange among code officials who have permitted or are in the process of permitting HFS, case studies of likely 
near-term HFS configurations, and a database of requirements incorporated in key codes and standards. The information repository will be augmented by workshops for code officials and station developers in jurisdictions that are likely to have HFS in the near future.

The national templates have guided DOE's effort to accelerate the development of key standards and model codes for hydrogen and fuel cell applications. With the help and cooperation of SDOs, CDOs, industry, and other interested parties, DOE has established a coordinated national agenda for hydrogen and fuel cell codes and standards. With the adoption of an RD\&D Roadmap by the Partnership and through its implementation by the CSTT, the DOE will help strengthen the scientific basis for requirements incorporated in these codes and standards that, in turn, will facilitate international market receptivity for hydrogen and fuel cell technologies.

\subsection{References}

1. ANSI, Overview of the U. S. Standardization System, $2^{\text {nd }}$ edition, 2007.

2. See http://www.iccsafe.org (accessed August 8, 2007)

3. See http://www.nfpa.org (accessed August 8, 2007)

4. See http://www.hydrogen.gov/regulations (accessed August 8, 2007)

5. See 29CFR Part 1910.103 and http://www.osha.gov (accessed August $8,2007)$

6. See http://www.cganet.com/isotc197 (accessed August 8, 2007)

7. See http://www.csa-america.org (accessed August 8, 2007) 


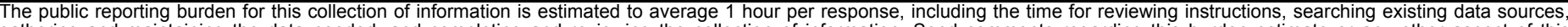

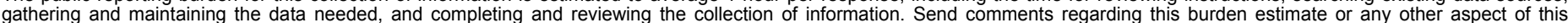

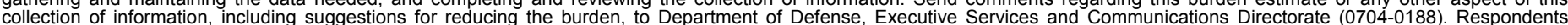

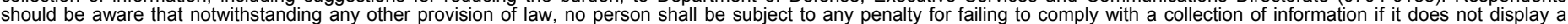

should be aware that notwithstanding

PLEASE DO NOT RETURN YOUR FORM TO THE ABOVE ORGANIZATION.

\begin{tabular}{|c|c|}
\hline $\begin{array}{l}\text { 1. REPORT DATE (DD-MM-YYYY) } \\
\text { May } 2010\end{array}$ & $\begin{array}{ll}\text { 2. } & \text { REPORT TYPE } \\
\text { Conference Paper }\end{array}$ \\
\hline
\end{tabular}

National Agenda for Hydrogen Codes and Standards

3. DATES COVERED (From - To)

4. TITLE AND SUBTITLE

5a. CONTRACT NUMBER

DE-AC36-08-GO28308

5b. GRANT NUMBER

5c. PROGRAM ELEMENT NUMBER

6. AUTHOR(S)

C. Blake

5d. PROJECT NUMBER

NREL/CP-560-48306

5e. TASK NUMBER

BB076110

5f. WORK UNIT NUMBER
7. PERFORMING ORGANIZATION NAME(S) AND ADDRESS(ES)

National Renewable Energy Laboratory

1617 Cole Blvd.

Golden, CO 80401-3393

9. SPONSORING/MONITORING AGENCY NAME(S) AND ADDRESS(ES)
8. PERFORMING ORGANIZATION REPORT NUMBER

NREL/CP-560-48306
10. SPONSOR/MONITOR'S ACRONYM(S)

NREL

11. SPONSORING/MONITORING AGENCY REPORT NUMBER

12. DISTRIBUTION AVAILABILITY STATEMENT

National Technical Information Service

U.S. Department of Commerce

5285 Port Royal Road

Springfield, VA 22161

13. SUPPLEMENTARY NOTES

14. ABSTRACT (Maximum 200 Words)

This paper provides an overview of hydrogen codes and standards with an emphasis on the national effort supported and managed by the U.S. Department of Energy (DOE). With the help and cooperation of standards and model code development organizations, industry, and other interested parties, DOE has established a coordinated national agenda for hydrogen and fuel cell codes and standards. With the adoption of the Research, Development, and Demonstration Roadmap and with its implementation through the Codes and Standards Technical Team, DOE helps strengthen the scientific basis for requirements incorporated in codes and standards that, in turn, will facilitate international market receptivity for hydrogen and fuel cell technologies.

15. SUBJECT TERMS

Hydrogen; Codes and Standards; national agenda; fuel cells

16. SECURITY CLASSIFICATION OF:
\begin{tabular}{|l|l|l|}
\hline $\begin{array}{c}\text { a. REPORT } \\
\text { Unclassified }\end{array}$ & $\begin{array}{c}\text { b. ABSTRACT } \\
\text { Unclassified }\end{array}$ & $\begin{array}{l}\text { c. THIS PAGE } \\
\text { Unclassified }\end{array}$ \\
\hline
\end{tabular}

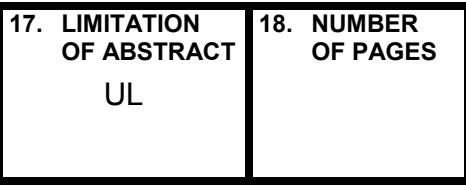

19a. NAME OF RESPONSIBLE PERSON

19b. TELEPHONE NUMBER (Include area code) 